\title{
Temporal Landscapes of Morality in Narrative: Student Evaluation in a Thai Parent-Teacher Conference
}

Kathryn M. Howard

University of Pennsylvania, kmhoward@gse.upenn.edu

Follow this and additional works at: https://repository.upenn.edu/gse_pubs

\section{Recommended Citation}

Howard, K. M. (2007). Temporal Landscapes of Morality in Narrative: Student Evaluation in a Thai ParentTeacher Conference. Retrieved from https://repository.upenn.edu/gse_pubs/193

Howard, K. M. (2008). Temporal landscapes of morality in narrative: Student evaluation in a thai parent-teacher conference. Discourse \& Society, 19(2), 163-186. doi:10.1177/0957926507085951

This paper is posted at ScholarlyCommons. https://repository.upenn.edu/gse_pubs/193

For more information, please contact repository@pobox.upenn.edu. 


\title{
Temporal Landscapes of Morality in Narrative: Student Evaluation in a Thai Parent-Teacher Conference
}

\begin{abstract}
As many scholars have noted, narrative is a primordial human tool for making sense of life experience (Brockmeier, 2000, Ochs \& Capps, 2001). While often described as a mode of relating experience that organizes events along temporal dimensions, research has also shown how participants in narrative activity explore the experiential logic of events by theorizing and evaluating the causes, consequences, responses and attempts to deal with problematic or unexpected situations (Ochs et al, 1992, Stein \& Glenn, 1979). This paper explores how educators and parents evaluate the moral identity of a problematic student through narrative activity in a Thai parent-teacher conference. Drawing on Taylor's (1989) conceptualization of "the good" as a moral space of questions within which modern persons orient themselves, the paper extends Taylor's metaphor of orienting persons in moral space to orienting them in time. Focusing in particular on the use of tense, aspect and modality in temporal perspective taking (Andersen, 1997), the analysis focuses on how narrators discursively configure an ideal moral landscape which narrated persons are temporally positioned within-- as having realized or having failed to realize "the good".
\end{abstract}

\section{Keywords}

narrative, temporality, identity, morality, parent-teacher conferences, modality, aspect, Thai, Thailand, education

\section{Comments}

Howard, K. M. (2008). Temporal landscapes of morality in narrative: Student evaluation in a thai parent-teacher conference. Discourse \& Society, 19(2), 163-186. doi:10.1177/0957926507085951 


\title{
Paper for DISCOURSE \& SOCIETY
}

Temporal Landscapes of Morality in Narrative:

Student Evaluation in a Thai Parent-Teacher Conference

\author{
Kathryn M. Howard \\ University of Pennsylvania
}

VERSION \#2: August 31, 2007

Address for proofs and offprints:

University of Pennsylvania

Graduate School of Education

3700 Walnut St.

Philadelphia, PA 19104

author email: kmhoward@gse.upenn.edu

Short Title: Temporal Landscapes of Morality

Size: 8,500 words, $144 \mathrm{~KB}$ 


\begin{abstract}
As many scholars have noted, narrative is a primordial human tool for making sense of life experience (Brockmeier, 2000, Ochs \& Capps, 2001). While often described as a mode of relating experience that organizes events along temporal dimensions, research has also shown how participants in narrative activity explore the experiential logic of events by theorizing and evaluating the causes, consequences, responses and attempts to deal with problematic or unexpected situations (Ochs et al, 1992, Stein \& Glenn, 1979). This paper explores how educators and parents evaluate the moral identity of a problematic student through narrative activity in a Thai parent-teacher conference. Drawing on Taylor's (1989) conceptualization of "the good" as a moral space of questions within which modern persons orient themselves, the paper extends Taylor's metaphor of orienting persons in moral space to orienting them in time. Focusing in particular on the use of tense, aspect and modality in temporal perspective taking (Andersen, 1997), the analysis focuses on how narrators discursively configure an ideal moral landscape which narrated persons are temporally positioned within-- as having realized or having failed to realize "the good".
\end{abstract}

Key Words: narrative, temporality, identity, morality, parent-teacher conferences, modality, aspect, Thai, Thailand, education 


\section{Author Biography:}

Kathryn M. Howard is an Assistant Professor of Education at the University of Pennsylvania. Her research explores processes of language socialization in linguistically diverse communities in formal (e.g., classroom) and informal (e.g., home or play group) educational settings. Her ethnographic, discourse analytic research in Northern Thailand has examined the social practices of respect, politeness and intimacy among preschool and school-aged bilingual children, and how these practices mediate social relationships and identity in both the local vernacular and the national standard language. 
"To know who I am is a species of knowing where I stand. My identity is defined by the commitments and identifications which provide the frame or horizon within which I can try to determine from case to case what is good or valuable, or what ought to be done, or what I endorse or oppose" (Taylor, 1989: 27).

Narrative is a powerful tool for the interpretation of experience. By juxtaposing and relating events on a narrative timeline, we as human beings explore, display, and assert our understandings of the relationships between events in our experience and the relevance of those events for our current and future ways of being. Through narrative we attempt to grasp the continuity of our experience over time, and by grasping this continuity we are able to articulate where we stand in relation to moral frameworks. Such orientation in moral space, as Taylor (1989) has pointed out, is a necessary basis for the modern conception of self. This paper explores narrative as an activity in which frameworks of moral evaluation are configured, and in which persons are evaluated in relation to these frameworks. While these frameworks are often conceptualized metaphorically in spatial dimensions, I argue that conversational narrative provides a means for configuring temporal landscapes of moral evaluation by virtue of a) its structural organization and b) the use of grammatical tense/aspect/modality within the logical and temporal organization of narrative. In the narrative genre, speakers orient themselves and others in relation to discursively configured realized, existent and hypothetical worlds. 
According to Taylor, modern subjects draw on morality as an interpretive framework to make sense of experience and to imbue action with significance. Morality provides the "background we assume and draw upon in any claim to rightness" (8-9). Defining morality consists not only in classifying social obligations according to some external sense of "right" action, but also in understanding "what makes life worth living"; a sense of morality includes notions such as "what it is good to be" and "the nature of the good life" (3-4). This 'good life' of modern morality is situated in the ordinary conduct of work and family life, rather than being defined in terms of some higher spiritual ideal.

Taylor argues that the modern moral compass supplements or supplants the moral directives of "objective" institutions (such as religion) in modern life: So, how do modern subjects navigate their moral worlds? Three basic elements of "moral thinking" are outlined by Taylor-a sense of obligation to and respect for others, a sense of what makes life meaningful, and a sense of dignity. This sense of dignity is concerned with "the characteristics by which we think of ourselves as commanding (or failing to command) the respect of those around us" (15). The moral framework guiding our responses to problematic and unexpected events is referred to by Taylor as "the good," which he views as a moral space of questions within which we orient ourselves: "the notion of self... is meant to pick out this crucial feature of human agency, that we cannot do without some orientation to the good, that we essentially are (i.e., define ourselves at least inter alia by) where we stand on this" (33).

In narrative activity, speakers discursively configure or presuppose these moral frameworks for evaluating conduct and action. Narrative, like life, often presents problems, or unexpected turns of events, which must be dealt with and responded to by 
characters in the narrative drama as well as participants in the storytelling (narrative) event: These problems raise questions about how to respond, and the modern moral compass that Taylor describes helps narrators to make sense of persons' responses and moral reactions. In narrative activity moral identities (including that of the participants in the event of narration) are explored as narrators represent and evaluate the actions and circumstances leading up to and following problematic events. The analysis presented here extends Taylor's metaphor of orienting in moral space, to a notion of orienting within moral landscapes that are constituted in temporal dimensions. Narrative characters' actions, experiences and characteristics are evaluated in relation to discursively constructed worlds that are expected, normative, and desirable.

According to Taylor, modern conceptualizations of the good are not defined as a set of rules to live by. Instead, the good is a set of the right answers to questions about our manner of living the ordinary life: "We take as basic that the human agent exists in a space of questions. And these are the questions to which our framework definitions are answers, providing the horizon within which we know where we stand and what meanings things have for us" (29). If one understands the good as a framework of answers to questions, and sees the questions as partially composed of "what ought to be done", and "what it is good or valuable to be", then the answers must constitute those responses, attempts, and methods for dealing with problems and circumstances, the description and evaluation of which are at the very core of narrative activity. Moral frameworks consist of real or hypothetical worlds in which certain actions and ways of being occur.

An analysis of narrative time must go beyond the notion of narrative as 
representing a sequence of events in a given time frame (e.g., past, present, future).

Instead, narrative is a medium through which past, present and future are brought together in a unity of relevance and consciousness (Brockmeier, 2000, Heidegger, 1953, Ochs, 1994, Ricoeur, 1981). The story genre evokes a relevant past which has an impact on the present and implications for the future: "The existential 'now' is determined by the present of preoccupation, which is a 'making-present,' inseparable from awaiting and retaining" (Ricoeur, 1981: 169). Not only do we bring the past to bear on the present and future, but we also bring the present to bear on the past, or on the future. ${ }^{i}$ By relating our quests in narrative, which are brought to bear on our actual situations and understood in terms of their consequences for our destiny, we create an understanding of who we are and who we have become: "repetition for Heidegger means more than a mere reversal of the basic orientation of care toward the future; it means the retrieval of our most basic potentialities inherited from our past in the form of personal fate and collective destiny" (Ricoeur, 1981: 176). The weight of the past, then, plays a role in defining who we have become, temporally positioning us in relation to the good.

Moral evaluation in educational settings

Parent-teacher conferences are activities in which the teacher presents a report on the successes and failures of the student. As representatives of a powerful institution, teachers and administrators communicate to parents the institutional expectations and requirements by which a student's actions may be judged. This moral evaluation of the student involves social stratification, as the student gets identified in terms of how he or she compares with other students of the same age and level. The way in which educators 
identify, characterize, and evaluate students is highly consequential, impacting students' educational, social, and affective trajectories. Mehan (1996) argues that the identification of students — by being labeled e.g., 'gifted', 'normal', or 'learning disabled'— is produced in multiple events, genres, and registers, and involves the progressive objectification of perceived student attributes as these discourses of identification become further removed from the contextually contingent behavior of the student. This process of identification "structures students' educational careers by opening or closing their access to particular educational opportunities" (Mehan, 1996: 271). Fleeting and seemingly insignificant events in which students are characterized, evaluated, and identified are powerful because they form a link in a chain of events through which particular identities get stabilized, solidified, and "thickened" such that they become more 'real' for both institutional agents making decisions that affect a student's trajectory, and for the student herself (Holland \& Lave, 2001, Wortham, 2003, 2006). These events of identification reproduce social structure through the application of category labels such as "normal" or "disruptive", and characterize individual students as typically thinking, feeling, and acting in particular ways.

Parent-teacher conferences are one site in which such identification takes place. They are described as events in which accounts and evaluations of student progress, achievement, and behavior feature prominently (Baker \& Keogh, 1995, Garcia Sanchez \& Orellana, 2006, Pillet-Shore, 2003a). In the parent-teacher conference presented here, the student is evaluated as someone who violates the obligations and expectations established by convention, by the institution, and by the typical actions of other students. In Taylor's (1989) terms, teachers develop and explain their perspective on what 
constitutes the good, and evaluate students in relation to that perspective. But the student is not the sole story personage whose identity falls under scrutiny at such meetings: When problems arise, the parents, teachers, and program administrators are all considered responsible for taking appropriate actions to resolve them. The conference also involves the characterization and evaluation of the parents' and the teachers' conduct related to the student (Baker \& Keogh, 1995, Garcia Sanchez \& Orellana, 2006, Pillet-Shore, 2003b).

\section{Data and Methods: The Parent-Teacher Conference}

This paper examines the discursive construction of moral identity in a parentteacher conference that occurred in a Thai college setting. The data used for this study comes from a meeting between a student's father and the program administrator of a teacher preparation program at a Teacher's College in Bangkok Thailand. ${ }^{\mathrm{ii}}$

Teachers - concerned about the academic performance of a 20 -year-old female student approaching the final year of this three-year teacher certification program - asked the student's father to attend a parent-teacher conference. According to her teachers, this student's performance in the program had been problematic from the start. Throughout much of the conference, the program director is speaking to the father about the student, and another teacher joins the conference later. Although the student was also expected to join the conference, she failed to attend. The conference lasted approximately forty-five minutes and included three participants: Professor Fah is a female professor and director of the teacher-training program; Po is the father; and Mek is a male teacher who joined the conversation later in the session. The conference was audio taped with the participants' permission, and transcribed by a native speaker. ${ }^{\text {iii }}$ 
Over the course of this meeting the program director delivers, piece by piece, the bad news to Po about his daughter's situation in school and its implications for her academic future. The student has failed to fulfill several of the program requirements, including a test and an internship, and she has an extremely low grade point average that is not adequate for graduation from the program. Po indicates that he was not aware of the problem, and that he lives too far from the school to stay informed about her progress. Despite the fact that the situation is characterized by the program director as being beyond the point of no return (i.e., that there is no way that the student will be able to graduate), she entertains a delicate negotiation with Po for much of the conference by describing the student's actions and leaving him to conclude the actual consequences of the situation.

Participants in parent-teacher conferences are generally focused on the central problematic situation of a student's performance in school. This commonly held understanding about the goals of parent-teacher conferences frames participants' interpretation and participation in this event. As long as the meeting continues and no other activity frame is keyed (such as talk about other matters), the participants draw on their expectations about this event in order to interpret ongoing talk. To the extent that talk within this event explores causes, consequences, and responses to the central narrative problem of the student's academic failure, the entire meeting is treated in my analysis as narrative activity, or more specifically as a conversationally co-constructed "story" (Ochs et al. 1992). While much work on narrative conceptualizes this form of discourse as a largely monologic activity (Labov, 1972), narrative analysis within discourse studies treats it as a dialogic and highly interactive activity in which 
conversational participants co-author the discourse either through active contributions or through visible displays of attention or stance (Goodwin, 1984, Ochs et al, 1989, Quasthoff, 1997, Sacks, 1974). Within this storytelling activity there are multiple embedded, co-constructed narratives, with different participants as principle tellers, that together constitute episodes of the larger story.

\section{Narrative Logic and Narrative Structure in Evaluation}

Narrators in this parent-teacher conference sketch out moral landscapes and locate narrated actors temporally in relation to the obligatory, desirable, and normative worlds configured in those frameworks. This is accomplished and understood through a conjunction of the specific grammatical marking of temporality, the narrative exploration of the causes and consequences of action, and by the structural / thematic conventions of the narrative genre. ${ }^{\text {iv }}$ Previous work has elucidated the organization of narrative defining it in terms of its logical relationships, and characterizing it as a mode of discourse in which the causes and consequences of a central problematic event are explored. In their analysis of story comprehension, Stein and Glenn (1979) articulate an experiential logic of stories which includes a setting, initiating event (IE), response to the IE, attempts to deal with the IE, the resolution or consequences of those attempts, and reactions to such consequences. Similarly, Ochs et al. (1992) define a type of narrative activity called a story that is primarily concerned with understanding a problematic event: a story is "narrative activity which articles a central problematic event or circumstance arising in the immediate or distant past and the subsequent past, present, and future actions/states relevant to interpreting and responding to the problem" (43). 
Ochs et al. (1992) and Ochs \& Capps (2001) show that the experiential logic of narrative plays a particularly important role in the dialogic co-construction of moral stance in conversational narrative: As explanations of the causes and consequences of problematic or unexpected events, stories build theories of experience that are made available to be challenged and negotiated, including the appropriateness of the actions, beliefs, and motivations of story characters. This dialogic problem-solving nature of narrative provides an important resource for morally positioning narrative characters and participants. Stories are always recounted from a particular perspective, and because they address a problematic or surprising event, this perspective often constitutes a moral stance: "Recounting the violation and taking a moral stance toward it provide a discursive forum for human beings to clarify, reinforce, or revise what they believe and value" (Ochs \& Capps, 2001: 46).

Narrative discourse contains different phases that provide varied resources by which narrators evaluate moral identities. In the story preface, the narrator secures the attention and interest of co-participants, characterizes the nature of the upcoming story, and seeks alignment for holding the floor over multiple turns (Quasthoff, 1997, Sacks, 1974). Story settings provide background information about the time, place, participants, and circumstances of the action presented in the narrative (Labov, 1972). The background information included in narrative settings provides frameworks for understanding and explaining the events delineated in the narrative (Ochs \& Capps, 2001). In the complicating action, stories proceed through webs of logic and sequence that underlie the exploration of initiating events along with their causes, attempts to deal with the events, consequences, and protagonists' responses and reactions to those events (Ochs \& Capps, 
2001).

In order to gain an understanding of how these narrators draw on the discursive resources of story structure, story logic, and grammar, I will first use Ochs \& Capps' (2001) framework to analyze the basic story logic contained in the narrative activity that occurs throughout this parent-teacher conference. At the beginning of this meeting, the program director, Professor Fah, lays out what she sees as the basic problem to be addressed in this meeting: the focal student's low achievement and failure to fulfill requirements. This introductory narrative discourse also describes the responses of students and teachers to this problem, various attempts to deal with it, the consequences of these responses and attempts, and reactions to these consequences. In addition, conarrators explore various possible reasons (causes) for the student's poor performance. The narrative depicts an unsuccessful student who has failed to complete several program requirements, and who has received very low grades for her work, despite repeated attempts by teachers and fellow students to intervene. This early and central episode of the story sketches the following logic:

1. Problems (Initiating Events):

- the student has failed to start an internship;

- the student has failed to take a test, leaving one course unfinished;

- the student has received unacceptably low grades.

2. Responses to the problem:

- the teachers do not know what to do.

3. Attempts to deal with the problem: ${ }^{v}$

- the teachers sent someone to find the daughter when she failed to attend the 
meeting at which internships were assigned.

\section{Consequences:}

- no resolution of the problem, the problem is getting progressively worse;

- the student will not be able to graduate;

- the student always gets the worst score, which is bad for her self-esteem.

Once the current, problematic state of affairs has been explicated, the program director takes the story back in time, to a period when she first noticed the student's problems, providing the nature of the problem, as well as her response and attempts to resolve it, as represented in the following list.

1. Problem leading to the Initiating Event:

- the student's language skills were noted by the program director and teachers to be inadequate during her first year.

2. Responses to the problem:

- none.

3. Attempts to deal with the problem:

- the program director discussed the student's low language proficiency with her;

- the teachers talked to the student about the problem.

\section{Consequences:}

- the student expressed her desire to remain in the program and claimed that she was highly motivated to improve her English.

5. Reaction (to student's claims):

- the student is allowed to stay in the program.

This second episode of narrative activity explores the web of causes and 
consequences leading up to the student's current problem, and the program faculty's actions in addressing the problematic situation. After this narrative episode, the story continues to be told in a similar fashion, as the co-narrators weave in additional story elements that explain the story's problem, lay out possible consequences, evaluate the methods, and attempts to deal with the problem by various story characters, or provide accounts in defense of their own methods and actions.

\section{Establishing the Frame in the Story Preface}

In the same way that diagnosis of a problem can organize the talk and interpretation of talk in a patient's visit to a doctor's office, the implicit goal of parentteacher conferences - discussing, evaluating and problem-solving the performance of a student—organizes the talk within this activity. Very soon after the father's arrival the program director begins her delivery of the news by eliciting his opinion of his daughter.

Segment 1: Framing the parent-teacher conference. (Professor Fah, program director; Po, the father). ${ }^{\text {vii }}$

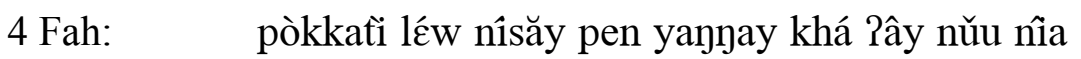
'Usually, how is her personality, that child?'


'It is, mm, as far as I can tell,'

$6 \quad$ mal hel pen lay

'I don't see anything wrong.'

7 Fah: $\quad 100$ haD

'Really?'

8 Po: khap

'Yes.' 
By eliciting Po's perspective on his daughter, Professor Fah establishes a frame of interpretation for talk in this meeting: that it centers on trouble. In line 4, the professor asks Po to characterize his daughter's "usual" demeanor, to which he supplies a hedged and non-committal response "as far as I can tell I don't see anything wrong." Professor Fah immediately displays a stance of non-alignment toward this assessment of the student's character. Her utterance in line 7 is an unspecified interrogative which locates the entire previous utterance as a problem, and more specifically displays doubt about the previous statement. Her five-second pause after line 8 foreshadows a possible dispreferred response (such as disagreement), so it is also a sign of trouble. After this display of her non-alignment to Po's characterization of his daughter as having no problems, and given that the participants in this activity know that parent-teacher conferences are meant to assess the progress of students, Professor Fah's talk in this story preface foreshadows her negative evaluation of the student.

\section{Configuring a Conventional Grid in the Story Setting}

With the interpretive frame firmly established in the story preface, Professor Fah's story setting launches a description of the program, its requirements, and current students' typical activity in the program. This setting (in Segment 2) configures a grid of conventionality as necessary background for interpreting the moral force of the events to be recounted in the later phases of the narrative.

Segment 2: Configuring the conventional grid

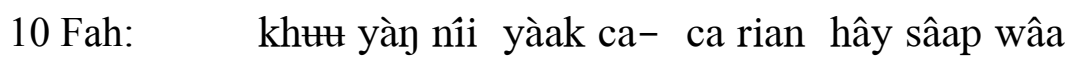


'It's just that, I would like- like to inform you that,'

11 Po: khap

'Yes?'

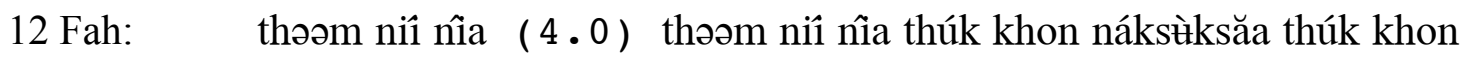
'This semester, (4.0) this semester everybody, all the students'

13 ca t0 fDRDaan

'will have to do an internship.'

14 Po: $\quad$ khap

'Yes.'

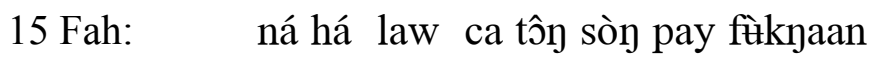

'Okay? We have to send them for an internship.'

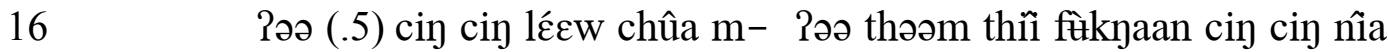
'Uh, (.5) actually, the section- uh, the semester for an internship, in actuality'

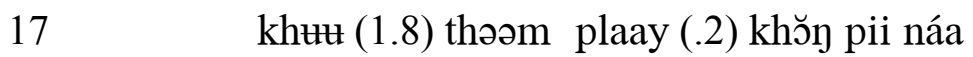

'is (1.8) the final semester (.2) of next year.'

18 Po: khap

'Yes.'

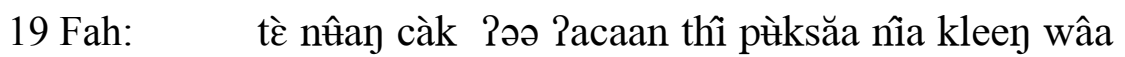
'But because, uh, the advisors fear that'

n- n- naßs0ksa日 ca mii panha日 Calay

'the s- s- students may have some problems,'

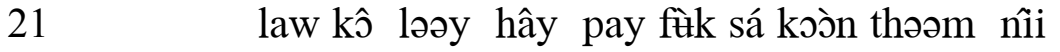

'we therefore had them do an internship this semester.'

22 Po: khap

'Yes.'

23 Fah: [na[ha!]

['Okay?']




[ 'She- ] she told me that too.'

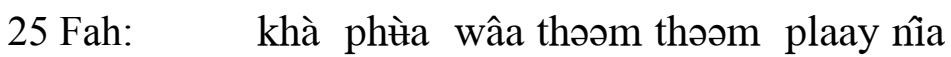

'Yes. In case, the- the last semester,'

26 thal khay salmalt ha日 Caan tham da 100y

'if any students could find a job,'



'they themselves would be fine.'

28 Po: khap

'Yes.'

29 Fah: $\quad$ cha mal halman ca day cop lew nat

'Right? So they will graduate a bit early.'

30 Po: khap

'Yes.'

31 Fah: daf Daan tham lew nat

'Get a job a bit early.'

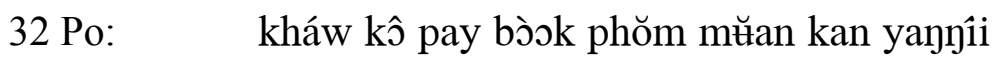

'She also came to tell me that."

In this story setting the program director informs the student's father of the current program requirements and the progress of other students in the program.

Professor Fah characterizes internships as an institutional requirement, the timing of which has been moved forward from a later semester to an earlier one by the program in which the students are enrolled. Fah then provides a warrant for that program decision, describing the felicitous personal and financial benefits of earlier internships-- graduating early and getting a job early-- and explains that the students' participation in internships will allow them to reach the valuable goals of graduating and working. This narrative setting also represents the normativity of internships within the program, reporting that "everybody, all the students," must conduct them. 
In this narrative setting, Professor Fah explains institutionally authorized program requirements and relates the desirability of conducting an internship as a valuable method of achieving socially acceptable goals and avoiding socially undesirable problems.

Internships are also characterized as normative activities in the sense that students are expected to do them, and in the sense that "everybody" does them. The narrative setting, then, establishes a conventional grid ${ }^{\text {viii }}$ for students in this academic program, configuring the dimensions of what is institutionally expected of them, what is normative among those students, and what is desirable or socially acceptable for the students to do. This conventional grid serves as a moral landscape in relation to which individual students can be evaluated.

\section{Complicating Action}

Following the setting phase of the story, Fah describes the complicating action: specific past events leading up to the initiating, or problematic situation.

Segment 3: Complicating action

33 Fah: $\quad k h a \square(.8)$ ta ni[hil (.4) phIan khat maa kan

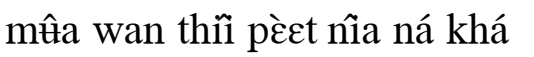
'Yes. (.8) Now, (.4) her classmates all came on the eighth.'

34 Po: $\quad$ khap

'Yes.'

35 Fah: $\quad$ maa cDo kap Lacaan liaploDy

'They all came to see the teachers already.'

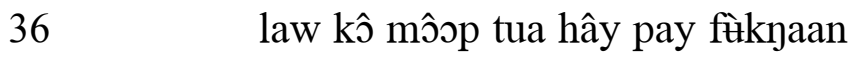

'We assigned each of them an internship,'

37 Po: khap

'Yes.'

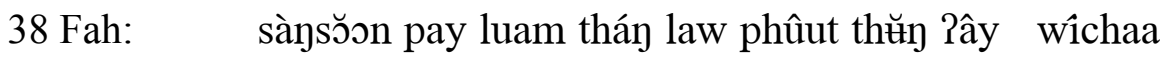


'Having instructed them, we also spoke about the courses'

41 Po: khap

'Yes.'

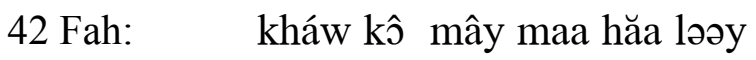

'She didn't come at all.'

43 Po: $\quad 100$ khap

'Really?'

44 Fah: haZ(.8) hal phपan taam

'Yes. (.8) We sent her friends to find her.'

In the narrative setting from segment 2, Professor Fah had explained the problems with not having an internship, as well as the benefits of having one. In segment 3 , she recounts the attempts of the teachers to enroll students in internships and advise them on their progress through the program at a required advising meeting. She reports that all of the other students attended this advising meeting and were assigned internships. And finally, Professor Fah characterizes the advising meeting as the place where students could learn about these internships and obtain other important information about their academic program. In this complicating action, then, Professor Fah continues to configure a conventional grid, against which Po's daughter will be evaluated, by constructing a model of normative actions performed by most students in response to the situation. In stark contrast to the other students' successful fulfillment of obligations, Professor Fah then recounts Po's daughter's failure to seek an internship or attend the 
advising meeting. This juxtaposition situates Po's daughter outside the conventional grid, in contrast to the norm set by the other students' actions.

Up until this point, Fah has accommodated Po's stated perspective on his daughter (that she is usually "okay"), by maintaining a distance from the narrative problem, gently leading up to it through an elaborate story setting and complicating action that together establish a conventional grid for interpreting the conduct of this particular student. After having mentioned this first, and most major, problem, a floodgate of problems seems to burst open, breaking her story free from these polite constraints. In line 45 , she begins relating a series of problems with the student's academic endeavors.

Segment 4: Narrative problems

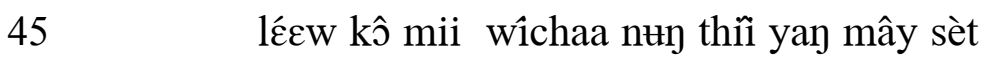
'And there is one course she hasn't finished yet.'

47 Po: $\quad$ प्रा

'Oh?'

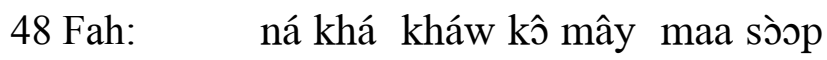
'Okay? She didn't come to take the test.'

49 Po: $\quad 100$ khap

'Really?'

50 Fah: $\quad$ kap Dacaan

'With the teacher.'

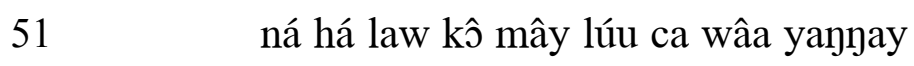

' Okay? And so we don't know what to do.'

52

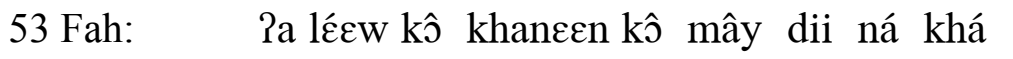


'Uh, and her grades are not good, either.'

54 Po: $\quad 100$ khap

'Really?'

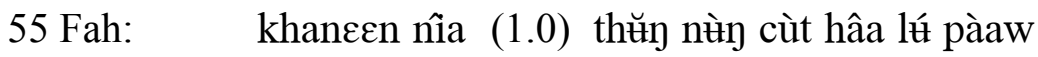

'As for the grades (1.0) whether they reach 1.5,'

$56 \quad$ kㅐma salp

'I'm not sure.'

57 Po: $\quad$ पoßy rian y므

'Oh! She studies badly.' ((surprised))

58 Fah: $\quad$ khal ca mall cop Daw

'Yes. She will not be able to graduate.'

59 Po: $\quad 100$ khap

'Really?'

$60 \mathrm{~T}: \quad$ kha!

'Yes.'

In segment 4, Professor Fah relates various ways in which this student has failed to meet program requirements and expectations. While in segment 3 she had positioned the student in relation to a narratively configured conventional grid, in segment 4 the professor characterizes the student's conduct as unconventional in relation to a commonly understood, institutionally authorized framework of evaluation, such as taking final exams and maintaining a reasonable grade point average. Fah explains that the teachers do not know how to resolve these problems, and finally suggests that a major consequence of the unresolved problematic situation is that the student will not be able to graduate. Po continues to maintain his own narrative perspective, expressing surprise and lack of knowledge about his daughter's performance, perhaps as means of accounting for his own failure to intervene earlier in his daughter's academic troubles. 
Professor Fah discursively configures moral frameworks that can be used to make sense out of Po's daughter's actions, and these frameworks make use of the kinds of moral thinking laid out in Taylor's (1989) argument, which includes considerations of obligations and respect, what makes life meaningful, a sense of dignity. Addressing considerations of obligations and respect, Fah explains the program requirements and faculty expectations that have been dashed by the student (flouting her faculty advisors, skipping exams, getting poor grades). Failing to conform to the norms set by other students' actions, as this student does, threatens her personal dignity (the ability to command the respect of others). And Fah's narration also references considerations of what makes life meaningful as she evaluates the desirability of achieving socially meaningful goals (graduating, getting a job) that this student will not achieve. These frameworks constitute the good- a moral landscape of evaluation- as narratively configured by the teacher. Represented within this interpretive framework, the actions of Po's daughter are situated outside the horizon of the good.

Moral Positioning through Tense, Aspect and Modality "To know who you are is to be oriented in moral space."

(Taylor, 1989: 28)

Within the conceptualization of the good developed above - as an obligatory, desirable, and normative world among alternates - the temporal dimension of morality is an important narrative resource for positioning people in relation to moral frameworks. This good world can be described as having been realized or unrealized, as existing or absent, and as hypothetically probably or improbable. This section focuses on how Thai 
narrators use grammatical markers of tense, aspect and modality to orient story characters and protagonists within the temporal landscape of moral evaluation. ${ }^{\text {ix }}$

Constructing the good: A hypothetical world.

Co-narrators must construct the moral frameworks and conventional grids that are used to orient narrated persons, including themselves, in relation to the good. In Thai, narrators use the temporal particle, $c a$ (usually future tense), ${ }^{\mathrm{x}}$ to sketch out the landscape of the normative and socially expected world of situations that constitute the good.

An obligatory future. The future tense and the modality of obligation are used (often together), mainly in the setting phases of narratives, to represent an ideal hypothetical world that fulfills social obligations and expectations. In Thai the following grammatical items are used to construct such a world:

- $\quad c a$ ('will/ would'): a pre-verbal particle marking a relative posterior time (future, conditional, habitual, hypothetical situations).

- $\quad t \mathrm{TL}$ ('must'): a modal verb of obligation (deontic modality).

In the following examples, in the process of configuring the conventional grid by which narrated situations and persons will be judged, the teacher depicts a hypothetical world in which certain acts are expected of moral actors.

Segment 5: (lines 11-12)

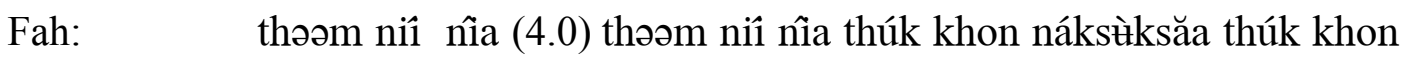
'This semester, (4.0) this semester everybody, all the students'



'will have to do an internship.'

Segment 6: (line 14) 


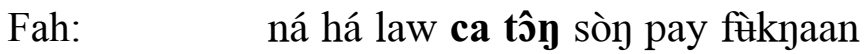

'Okay? We will have to send them for an internship.'

Segment 7: (line 90)

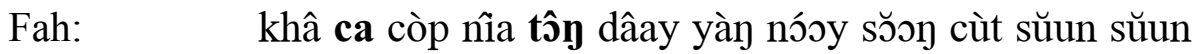
'Yes. To graduate, students must get at least 2.0.'

In these segments, Professor Fah uses the grammatical marking of future and obligation together to construct a hypothetical temporal frame for obligatory actions, describing would-be conduct that is socially or institutionally expected, such as doing an internship, sending students on internships, and getting a 2.0 grade point average.

A conditional future. The future particle ( $\mathrm{ca}$ ) also marks a conditional future, and in this narrative activity speakers use it to construct an ideal world that will result if certain felicitous actions are carried out. In segment 8 , for example, the teacher is describing the future situation that she believes would result from having an internship. If the students complete their internships now, they will later reap the benefits.

Segment 8: (lines 24-30)

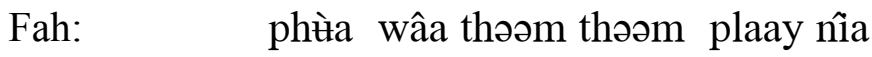

'In case, (during) the last semester,'

tha日 khay salmalt ha日 Daan tham dat 10Dy

'if any students could find a job,'

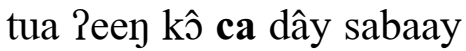

'they themselves will be fine.'

chaf mall halman ca daf cop lew not

'Right? So they will graduate a bit early.'

dal Daan tham lew nD

'Get a job a bit early.' 
Constructing the already good: A realized world

Co-narrators temporally position narrated persons in relation to moral frameworks by identifying them as individuals who have already performed moral actions, had moral experiences, or who already possess certain characteristics. Using the grammatical constructions that express completive, realized, perfect and experiential meanings, narrators represent a "good" world that has been realized through these experiences, actions or characteristics.

The already good. Co-narrators orient themselves and others within these temporal landscapes of evaluation by indicating that appropriate and expected actions have been completed or realized, which is accomplished (in part) by with the grammatical and lexical forms equivalent in meaning to "already":

- $k \square \square n:$ an adverb and preposition meaning "before"

- ri accomplishments that are completely or thoroughly done.

- $\quad l[\square w$ : a present perfect marker highlighting the current relevance of a preceding situation (sometimes translated 'already', with the emphatic nuance that term sometimes conveys) (Howard, 2000).

In segments 9 and 10, Professor Fah indicates that she and others have already taken actions that she had earlier narrated as lying within the domain of the good: For the program faculty, having assigned each student to an internship; for the students, having sought and secured an internship assignment.

Segment 9: (line 20): 


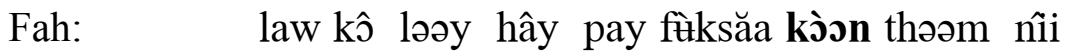

'And so, we gave them an internship before this semester.'

Segment 10: (lines 32-34):

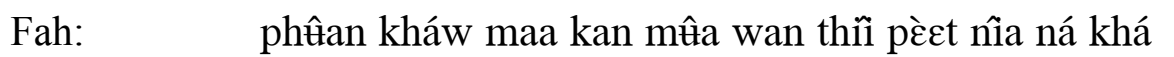

'Her classmates came together on the eighth.'

maa cㅁ kap Dacaan liapl[पy

'They all came to meet the teachers already.'

In these segments, teachers and all of the other students are described as having realized expected and normative actions, thus they are temporally positioned as lying squarely within the horizon of the good.

The experienced good. Co-narrators use experiential markers, resultative markers and perfect markers to describe a person's past experience of the good world, which places the experiencer within that world at the moment of the narrative telling. In this narrative, the experiential and resultative were used in this way:


some time prior to a reference point.

- wal : (lit. 'to put away') a completive/ resultative marker.

In the following example, Professor Fah uses these markers to characterize herself as having experienced the good, emphasizing that she had already had the experience of making attempts to deal with Po's daughter's problems. The use of the resultative marker indicates that this attempt was made not only prior to the narrated reference point (before the student finished her first year), but also that it had continuing material and/or emotional consequences that were relevant at the time the story was being recounted. The use of these two markers together emphasizes the realization of this relevant experience. 
Segment 11: (lines 62-66):

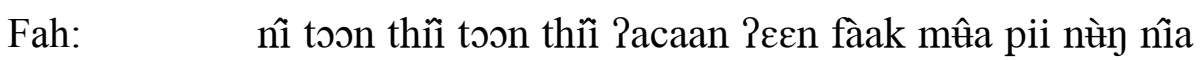

'When, when Professor Ann admitted her in the first year,'

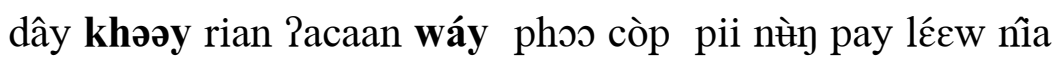

'I already had the chance to inform the professor that, when she had finished the first year,'

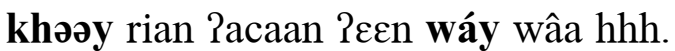

'I had already informed Professor Ann that hhh'

phasal khat nil mal khat dii

'her language was not so good.'

Here Professor Fah argues that she had already attempted to address problems with this student that were evident in the first year of her studies, by informing her colleagues that she had noticed problems with this student's language skills. By describing these actions the narrator represents herself as someone who has already taken appropriate steps in relation to the central problematic situation presented in the narrative.

Constructing the un-good: An unrealized world

Just as story characters and co-narrators can be morally evaluated by recounting how they have acted in ways that have allowed them to realize the ideal hypothetical world, they can also be oriented outside of the good by not having taken actions, had experiences, or possessing characteristics that would realize that world. These negative observations evaluate the student by directly invoking the ideal hypothetical world constructed as the good in earlier narrative segments, against which she is compared.

The not yet good: unrealized past actions. Those outside the realm of the "good" are depicted as not having realized expected, normative or appropriate past actions. In such instances, the grammatical negator $\mathrm{ma}$ I is found in utterances otherwise describing 
actions that would fit within the good. In the following examples, the teacher mentions required or expected actions that the student has failed to perform: coming to get an internship (an expectation mentioned in segment 3), finishing a course and taking a test (commonly understood expectations).

Segment 12: (line 41)

Fah: $\quad$ khat k0 maף maa hal $10 \square \mathrm{y}$

'She did not come at all.'

Segment 13: (line 44)

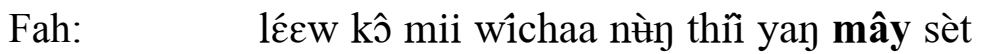

'And there is one course she still has not finished.'

Segment 14: (line 46)

Fah: $\quad$ khat kTImay maa s[Dp

'She also did not come to take the test.'

The not yet good: the lack of past experiences. Utterances containing the experiential marker are negated to depict a person who has never yet experienced a certain aspect of the "good":

- ma円 $k h \square \square y:$ negative + experiential, indicates a relevant situation which has not yet been experienced.

Segment 15: (lines 59-61)

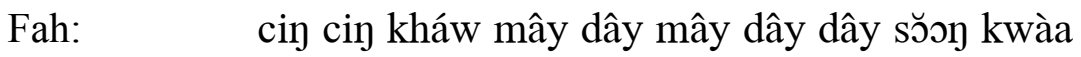
'In fact, she hasn't gotten, hasn't gotten more than 2.0.'

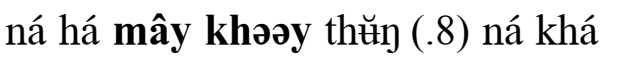

'Okay? She has never yet reached it, (.8) okay?'

In this example, Professor Fah reports that Po's daughter has not yet reached even a 
minimal grade point average in her courses.

The un-good: negative present states: The un-good are described as lacking positive qualities, through the use of negated stative verbs in the present time frame. It is noteworthy that the student and the things closely associated with her are frequently characterized as failing to represent positive qualities, rather than as being outright "bad". In segment 16, the student's grades are described as "not good", and in segment 17 she is described, by both father and teacher, as "not enthusiastic".

Segment 16: (line 50):

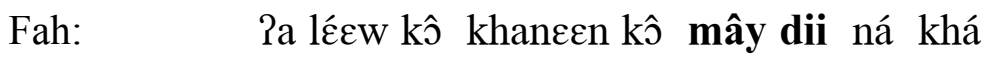

'And her grades are not good either, okay?'

Segment 17: (lines 80-81):

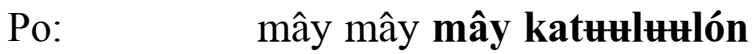
'She's not- not- not enthusiastic.'

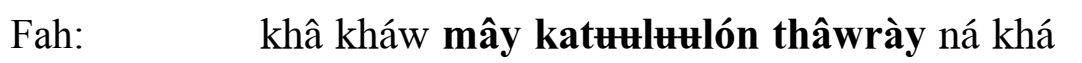
'Right. She is not very enthusiastic, okay?'

The unattainable good: impossible worlds. The student is also described as lacking the possibility to reach the "good", because current circumstances do not provide a route to achieving desired goals. In segment 18 , the teacher describes the consequences of the student's present circumstances-- not being able to graduate; and in segment 19, the teacher claims that there is no possible action she could now take in order to achieve the desired grade point average. ${ }^{\text {xii }}$

Segment 18: (line 55):

Fah: $\quad$ ca may cop $\quad$ aw 'She will not be able to graduate.'

Segment 19: (lines 94-95): 
Fah: $\quad$ sषQ tham thatrlay

'No matter how much she does,'

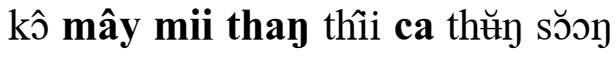

'there is no way that she will reach 2.0 .'

In these examples a description of a hypothetical good world (graduating, reaching a certain grade point average) marked by the Thai future marker, is collocated with terms expressing negative possibility indicating that the hypothetical good world is unattainable.

The future: A probable un-good world. The teacher also occasionally describes a likely future in which the student has not achieved normative goals and desired actions or outcomes. This is accomplished through the conjunction of the future particle and the negative marker, as in segment 20.

Segment 20: (lines 95-96)


'Her grades won't reach one, won't-'

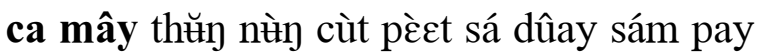
'she will not even reach 1.8.'

Tense, mood and aspect in narrative temporality

In narrative temporality, the weight of the past is brought to bear on who we are, as we orient toward a future of possible worlds (Brockmeier 2000; Ricoeur 1981). Our sense of morality involves orienting within the landscapes of moral evaluation that are configured, in part, through narrative activity as the right ways of responding to life's challenges. Temporality is the compass that establishes where we stand within that landscape: The hypothetical world of the good can be realized, existent and possible, or it can be unrealized, non-existent, and impossible. Narrators sketch out the landscape of 
moral evaluation, and position people within (or outside of) this realm through the evaluative power of temporal perspective-taking (Andersen 1997) in narrative. As Andersen argues, tense and aspect is used by speakers to convey "a particular perspective on an event or a situation, including temporal and aspectual attributes of the situation or event" (1). Tense, aspect, and modality play a crucial role not only in presenting perspectives on temporal relations along a chronological timeline, but also in displaying different perspectives on the moral standing of story tellers and protagonists.

\section{Conclusion}

Taylor (1989) describes morality as existing within a space of questions about what it is good or valuable to be and what makes life worth living in the everyday realms of our work and family. Moral thinking, in his view, involves a sense of obligation to and respect for others (what is obligatory), a sense of what makes life meaningful (what is desirable), and a sense of one's own dignity (e.g., what is normal). Narrative explores how actors respond to the questions that life poses, how they feel about, react to, and attempt to resolve problematic or unexpected situations. In the process of recounting such events, co-narrators negotiate evaluations of what is obligatory, normal, and desirable to be and do. Narrative activity not only draws upon presupposed frameworks of morality in constructing characterizations and evaluations of story characters, it is also a prime site for narrators to build and construct those frameworks for use in current evaluations. Narrators configure grids of evaluation that apply to the current circumstances just as they explicitly or implicitly link current descriptions to the metapragmatic models that "mediate" our sense of identity (Wortham 2001, 2006).

Ochs and Capps (2001) describe the power of narrative to legitimize expectations: 
By its very nature, narrative is a genre in which co-narrators not only depict and characterize the actions of narrated persons, but also configure the framework of interpretation for understanding the events thus depicted. Narrative settings often provide the backdrop against which interlocutors can interpret the problematic nature of events being depicted. As such, narrative settings are often used to elaborate and affirm the institutional, social, and conventional authority of the expectations that have been dashed by the story's central problematic event. In the data examined here, a student's parent and teacher are meeting to discuss her status as a student, as well as their roles as parent and teachers. In so doing, they characterize the student (and themselves) in relation to moral worlds that can be realized through the methods that each person employs in the avoidance and resolution of problems. This ideal moral landscape is sketched out in the story setting and complicating action, and constitutes a framework against which protagonists' thoughts, feelings and actions can be compared. The story's protagonists can be described as having realized this hypothetical, morally correct world through their actions, experiences and characteristics, thus orienting them within the temporal landscape of "the good". In this case, the problematic student's actions are set against the backdrop of institutional and conventional expectations as well as other students' normative behavior. She is described as not having realized the expected and normal conduct, as not possessing the characteristics associated with "normal" or "successful" students, and as unable to take actions that would place her in the realm of the "good" student.

The means by which teachers identify and frame children is consequential on a number of levels. It may be that the characterizations in this parent-teacher conference 
arose out of a chain of characterizations and identifications that impacted this student in ways not visible in this data. The interpretation of the student as built in this narrative activity will certainly be consequential for her future identity both as a student and as a daughter. Earlier studies have shown that American educators tend to evaluate students' success or failure in terms of internal dispositions (such as ability, behavior and psychological states) (Mehan et al, 1986). Mehan (1996) found that school psychologists, teachers, and parents drew on different factors to explain the academic difficulties of problem students: School officials and psychologists described the student in terms of stable, internal characteristics in numerical terms as compared to age-grade norms, while teachers and parents spoke about the student in more contextual terms, mentioning situational contingencies (such as task and motivation) and changes over time (such as changing interests). In this data, while internal factors are sometimes mentioned ("she is not enthusiastic", "her English is not so good") the Thai educators represent this student in ways similar to the American mother in Mehan's data: her failure is largely explained in situationally contingent (not attending a test, missing an advising meeting) and historical (changing from motivated to not enthusiastic) terms. Rather than identifying the student's internal and stable dispositions, the factors used in explaining her failure are largely unstable (e.g., lack of effort) leaving open a possible future in which the student could hypothetically succeed in academic endeavors, given the right circumstances. In Thai evaluations of students, it is notable that people are seen as becoming, rather than being, and as containing multiple potentialities across timescales across this lifetime and beyond. The discourses of evaluation seen here crucially involve characterizing the student as not yet good as opposed to bad, and as not possessing the characteristics of the 
good, as opposed to possessing negative qualities: She is characterized as un-good, rather than as positively bad. This conceptualization of the person allows for the possibility, and perhaps even assumes, that she will someday reach her potential as a good person, and walk in the sunny landscape of the good.

\section{Acknowledgments}

I would like to thank Dr. Shoichi Iwasaki who generously shared this data with me and Dr. Amy Meepoe Baron who transcribed and translated it. Feedback on earlier drafts from a number of colleagues was also crucial, including Cati Coe, Julia Déak, Hugh Mehan, Rachel Reynolds, and Christopher Thomas. With love and gratitude I thank my mentor, supporter and friend Elinor Ochs, who inspired this work in many ways. Any remaining errors and omissions are my own.

\section{References}

Andersen, R. (1997) 'According to Me: Learning to Take Temporal Perspectives in Discourse'. Los Angeles, CA

Baker, C. and Keogh J. (1995) 'Accounting for Student Achievement in Parent-Teacher Interviews', Human Studies 18: 263-300.

Bauman, R. (2004) A World of Others' Words. Oxford: Blackwell Publishing Brockmeier, J. (2000) 'Autobiographical Time', Narrative inquiry 10: 51-73.

Bybee, J., Perkins R. and Pagliuca W. (1994) The Evolution of Grammar. Chicago, IL: The University of Chicago Press

Garcia Sanchez, I. and Orellana M. F. (2006) 'The Construction of Moral and Social Identity in Immigrant Children's Narratives-in-Translation', Linguistics and Education 17: 209-39.

Goodwin, C. (1984) 'Notes on Story Structure and the Organization of Participation', in D. Atkinson and J. Heritage (Eds.), Structures of Social Action, pp. 225-46. Cambridge: Cambridge University Press.

Heidegger, M. (1953) Being and Time. Albany, NY: State University of New York Press Holland, D. and Lave J. (2001) History in Person. Santa Fe, NM: School of American Research

Howard, K. (2000) 'The Notion of Current Relevance in the Thai Perfect', Linguistics 38: 373-407. 
Iwasaki, S. and Ingkaphirom P. (2005) A Reference Grammar of Thai. Cambridge: Cambridge University Press

Labov, W. (1972) 'The Transformation of Experience in Narrative Syntax', in W. Labov (Ed.), Language in the Inner City: Studies in the Black English Vernacular, pp. 354-405. Philadelphia: University of Pennsylvania Press.

Maynard, D. (1990) 'Perspective Display Sequences and the Delivery of Diagnostic News', in D. Boden and D. H. Zimmerman (Eds.) Talk and Social Structure, pp. 164-92. Berkeley: University of California Press.

Mehan, H., Hertweck, A. and Meihls, J. (1986). Handicapping the Handicapped: Decision Making in Students' Careers. Stanford: Stanford University Press.

Mehan, H. (1996) 'The Construction of an Ld Student: A Case Study in the Politics of Representation', in M. Silverstein and G. Urban (Eds.), Natural Histories of Discourse, pp. 253-76. Chicago: The University of Chicago Press.

Ochs, E. (1994) 'Stories That Step into the Future', in D. F. Biber and E. Finegan (Eds.), Perspectives on Register: Situating Register Variation within Sociolinguistics, pp. 106-35. Oxford: Oxford University Press.

Ochs, E. and Capps L. (2001) Living Narrative. Cambridge: Harvard University Press

Ochs, E., Smith R. and Taylor C. (1989) 'Detective Stories at Dinnertime: ProblemSolving through Co-Narration', Cultural dynamics 2: 238-57.

Ochs, E., Taylor C., Rudolph D. and Smith R. (1992) 'Story-Telling as a Theory-Building Activity', Discourse Processes 15: 37-72.

Pillet-Shore, D. M. (2003a) 'Doing 'Okay' on the Multiple Matrix of an Assessment', Research on Language and Social Interaction 36: 285-319.

Pillet-Shore, D. M. (2003b) Selling out Their Kids? An Exploration of Parent-Caregivers' Delivery of Negatively-Valenced Information About Students in Parent-Teacher Conferences. Paper presented at American Education Research Association (AERA)

Quasthoff, U. M. (1997) 'An Interactive Approach to Narrative Development', in M. Bamberg (Ed.), Narrative Development: Six Approaches, pp. 51-83. Mahwah, NJ: Lawrence Erlbaum Associates, Inc.

Ricoeur, P. (1981) 'Narrative Time', in W. J. T. Mitchell (Ed.), On Narrative, pp. 165-86. Chicago: The University of Chicago.

Sacks, H. (1974) 'An Analysis of the Course of a Joke's Telling in Conversation', in R. Bauman and J. Sherzer (Eds.), Explorations in the Ethnography of Speaking, pp. 337-53. Cambridge: Cambridge University Press.

Smyth, D. (2002) Thai: An Essential Grammar. London and New York: Routledge

Stein, N. and Glenn C. (1979) 'An Analysis of Story Comprehension in Elementary School Children.' in R. O. Freedle (Ed.), New Directions in Discourse Processing, pp. 53-120. Norwood, NJ: Ablex.

Taylor, C. (1989) Sources of the Self: The Making of the Modern Identity. Cambridge: Harvard University Press

Wortham, S. (2001) Narratives in Action. New York: Teachers College Press

Wortham, S. (2003) 'Accomplishing Identity in Participant-Denoting Discourse', Journal of Linguistic Anthropology 13: 189-210.

Wortham, S. (2006) Learning Identity: The Joint Emergence of Social Identification and Academic Learning. Cambridge: Cambridge University Press 
${ }^{\mathrm{i}}$ Brockmeier (2000) notes that certain narratives, such as narratives of trauma and loss, are "static"-- destined to remain fractured and disjointed from the temporality of our life stories (67-68). These narratives must remain beside, and not integrated into, one's preceding or following life experiences, for there is no making sense of such tragedies. I would add, however, that these narratives also often constitute the inescapable emotional fabric of everything that follows, and the emotional filter over the memory of everything that preceded them.

ii In Thai colleges and universities parent-teacher conferences are conducted only under special circumstances at a time mutually agreed upon between the teacher and the parent In Thailand, unlike the United States, parents are considered to be the legal guardians of undergraduate students, thus information is shared more freely with the parents of college students than it is in the US context.

iii I am most grateful to Dr. Shoichi Iwasaki, who collected this data as part of a larger Thai language data corpus, and who generously shared the corpus with me and other scholars of the Thai language. I am also grateful to Dr. Amy Meepoe Baron who transcribed and consulted with me extensively on translations of this text. She and Ms. Jai Chenawongsa consulted with me on matters of Thai language grammar and use more generally. I must also gratefully acknowledge Dr. Supa Angkurawaranon and Dr. Ketckanda Jaturongkachoke, who have also consulted with me on matters of Thai language, grammar, and culture.

iv Bauman (Bauman, 2004) defines 'genre' as "a constellation of systemically related, cooccurrent formal features and structures that serves as a conventionalized orienting framework for the production and reception of discourse" (3).

"Another response to the problem remains implicit, namely the fact that the program director called the student's father to this parent-teacher conference.

vi This is similar to the way that doctors have been found to deliver "bad news" through "perspective-display sequences" (Maynard, 1990). In these sequences, doctors delay the delivery of bad news by attempting to elicit the patient's opinion on their own diagnosis. In this way, the doctor can design his delivery of bad news in a way that displays (partial) alignment with the patient's viewpoint. I would like to thank Jeanne Katzman for pointing this out.

${ }^{v i i}$ See Appendix I for transcription conventions used in the data segments.

viii This term was suggested by Elinor Ochs.

${ }^{\text {ix }}$ Grammatical description in this section draws on Iwasaki \& Ingkaphirom (2005), Smyth (2002), and on Bybee et al's (1994) typological, cross-linguistic description of the evolution, meaning, and use of tense, aspect and modality.

${ }^{\mathrm{x}}$ Thai does not have obligatory tense marking. $\mathrm{ca}$ is not an absolute tense marker, but rather indicates a time frame that is posterior relative to a presupposed reference point. Smyth (Smyth, 2002) refers to $c a$ as a marker of future tense, while Iwasaki \& Ingkaphirom (2005) refer to it as a marker of 'challengeability'. As such, it often allows an epistemic stance reading including some element of doubt or uncertainty. It has hypothetical, conditional, habitual (i.e. similar to 'would'), and relative future uses. xi These two items can be used in combination. 
xii Line numbers refer to the lines, consecutively numbered, in the transcript of the whole conference.

xiii There is a wide range of possibility modals in Thai, including pre-verbal modal auxiliaries, and serial verb constructions that are lexically determined and thus depend on the particular verb being used. For that reason they are too numerous to enumerate here. 